\title{
Comparative Analysis of Different Puberty Inhibiting Mechanisms of Two GnRH Agonists and the GnRH Antagonist Cetrorelix Using a Female Rat Model
}

\author{
CHRISTIAN ROTH, SABINE LEONHARDT, CHRISTOPH SEIDEL, HEIKE LUFT, \\ WOLFGANG WUTTKE, AND HUBERTUS JARRY
}

Children's Hospital [C.R., C.S.] and Division of Clinical and Experimental Endocrinology, Department of
Obstetrics and Gynecology [S.L., H.L., W.W., H.J.], University of Göttingen, Göttingen, Germany

\begin{abstract}
ABST
GnRH agonists are the established treatment of precocious
puberty caused by premature stimulation of gonadotropin secre-
tion. It has been reported that after an initial stimulation ("flare-
up") they reduce LH secretion by desensitization of pituitary
GnRH receptors. Little has been published about the use of
GnRH antagonists such as cetrorelix to control the onset of
puberty and whether they are potentially advantageous compared
with GnRH agonists. We conducted two multigroup experiments
(12 and 10 d, respectively) treating prepubertal/peripubertal fe-
male rats with either the GnRH agonist triptorelin or buserelin
and compared them with rats treated with the GnRH antagonist
cetrorelix and controls to assess the effects on pubertal progress
and serum hormones. In the second experiment, the effects of
buserelin and cetrorelix on gene expression of the GnRH recep-
tor, LH- $\beta$, FSH- $\beta$, and the alpha subunit genes in the pituitary
were also investigated. Cetrorelix, triptorelin, and buserelin re-
tarded the onset of puberty as determined by delayed vaginal
opening, lower ovarian weights, and lower serum estradiol lev-
els. However, although LH and FSH levels were stimulated by
both agonists, they were inhibited by cetrorelix. In the cetrorelix
\end{abstract}
versus buserelin experiment, pituitary gene expression of the $\mathrm{GnRH}$ receptor and LH- $\beta$ subunit were significantly lower in cetrorelix treated rats compared with controls whereas buserelin had little effect. Expression of FSH- $\beta$ and alpha subunit were stimulated by buserelin but not by cetrorelix. Even though all three of these GnRH analogues inhibited gonadal development and delayed the onset of puberty, the GnRH agonists had stimulating and inhibiting effects on the pituitary-gonadal axis whereas cetrorelix exerted only inhibiting effects. We conclude from this female rat model that cetrorelix may offer advantages for a more controlled medical treatment of precocious puberty compared with GnRH agonist treatment. (Pediatr Res 48: 468474, 2000)

$\quad$ Abbreviations
GnRH, gonadotropin-releasing hormone
CET, cetrorelix
TRIP, triptorelin
BUS, buserelin
RT-PCR, reverse transcriptase polymerase chain reaction

Onset of puberty is dependent on pulsatile release of hypothalamic GnRH from GnRH neurons (1). Premature release of GnRH causes central precocious puberty. GnRH agonists such as TRIP and BUS are the established treatment of central precocious puberty (2-4). Treatment with GnRH agonists causes an initial stimulation of the LH secretion ("flare-up"), which is followed by a low prepubertal LH secretion due to desensitization and/or down-regulation of pituitary GnRH receptors $(4,5)$. This method of treatment, however, is not without risks and side effects. Regular injections of these

Received October 26, 1999; accepted May 22, 2000.

Correspondence and reprint requests: Dr. Christian Roth, Universitätskinderklinik, Robert-Koch-Str. 40, 37075 Göttingen, Germany.

Parts of the studies were supported by a DFG-grant (Ja 398 (6-1).

This paper is part of the habilitation thesis of C. Roth. long-acting GnRH agonists are necessary to avoid a reactivation of the gonadotropin and gonadal steroid hormone secretion that occurs soon after treatment is discontinued (2).

Depending on the nature of the substitutions, synthetic GnRH analogues have either GnRH agonistic or GnRH antagonistic properties. The GnRH agonist TRIP (D-Trp ${ }^{6}$ )-GnRH differs from the native peptide in position 6 , the GnRH agonist BUS (D-Ser(tBu) $\left.{ }^{6}-\mathrm{NHEt}^{10}\right)-\mathrm{GnRH}$ differs in positions 6 and 10, whereas the GnRH antagonist CET acetate (Ac-D$\mathrm{Nal}(2)^{1}$,D-Phe $\left.(4 \mathrm{Cl})^{2}, \mathrm{D}-\mathrm{Pal}^{3}, \mathrm{D}-\mathrm{Cit}^{6}, \mathrm{D}-\mathrm{Ala}^{10}\right)-\mathrm{GnRH}$ contains substitutions in positions $1,2,3,6$, and 10 (6). CET is now in phase III clinical studies $(7,8)$ for suppression of gonadotropins and gonadal hormones in men and women and has been widely used for endocrine applications such as in vitro fertilization, influencing lipoprotein subclasses, and treatment of 
prostate cancer and benign prostate hyperplasia $(7,9-13)$. CET has a strong inhibitory action on hormone release and has a low frequency of side effects compared with other antagonists for which anaphylactoid reactions due to histamine release and immunosuppressive effects have been reported (14-16).

Little has been reported about the use of CET in controlling the onset of puberty and whether this GnRH antagonist offers advantages for regulating pituitary hormone secretion compared with GnRH agonists. Therefore, we treated prepubertal female rats with CET or GnRH agonists to investigate the effects on pubertal development, serum hormone levels, and the gene expression of GnRH receptor, LH- $\beta, \mathrm{FSH}-\beta$, and the alpha subunit in the pituitary.

\section{METHODS}

Animals, drugs, and serum hormones. Female Sprague Dawley rats were housed under standardized conditions (lights on $12 \mathrm{~h}$ from $0700 \mathrm{~h}$ to $1900 \mathrm{~h}, 25^{\circ} \mathrm{C}$ room temperature, 10 animals per cage). After randomization, in each cage were animals from all treatment groups. They had free access to water and were fed ad libitum. The doses of BUS, TRIP, and CET used have been shown to be effective in suppressing the gonadal hormones in previous experiments with rats $(17,18)$. In both experiments drugs were diluted with $\mathrm{NaCl} 0.9 \%$ to a volume of $0.4 \mathrm{~mL}$ for each injection. All animals were monitored for changes of the external and internal genitalia. Vaginal opening marked the first estrous cycle and the beginning of puberty (in controls at postnatal d 33-38). The studies were approved by the local ethical committee for animal experiments at the University of Göttingen.

Experiment 1-CET versus TRIP: Animals were randomized in five groups, each consisting of 12-16 animals. From d 25 to $\mathrm{d} 36(12 \mathrm{~d})$ rats were intraperitoneally injected once per day at $1800 \mathrm{~h}$ with either $1 \times 0.4 \mathrm{~mL} \mathrm{NaCl} 0.9 \%$ (placebo group), $1 \times 100 \mu \mathrm{g}$ or $1 \times 10 \mu \mathrm{g}$ CET (CET 100 or CET 10 group) or $1 \times 100 \mu \mathrm{g}$ or $1 \times 10 \mu \mathrm{g}$ TRIP (TRIP 100 or TRIP 10 group). Serum gonadotropins were measured at four different time points during treatment: $14 \mathrm{~h}$ after first injection; $24 \mathrm{~h}$ after third injection; $2 \mathrm{~h}$ after ninth injection; $14 \mathrm{~h}$ after last injection of drugs after decapitation in the morning. The first three blood samples were obtained by cannulation of the tail artery in slight ether narcosis and the fourth blood sample was collected from the trunk immediately after decapitation at $\mathrm{d} 37$.

Experiment 2-CET versus BUS: Three groups consisting of 38-41 animals per group were formed by randomization. From d 28 to $\mathrm{d} 37(10 \mathrm{~d})$ rats were intraperitoneally injected with either $2 \times 0.4 \mathrm{~mL} \mathrm{NaCl} 0.9 \%$ daily at $0700 \mathrm{~h}$ (placebo group), $1 \times 100 \mu \mathrm{g}$ CET daily at $0700 \mathrm{~h}$ or $2 \times 30 \mu \mathrm{g}$ BUS daily at $0700 \mathrm{~h}$ and $1800 \mathrm{~h}$. On d 37, rats of all three groups were decapitated $2 \mathrm{~h}$ after the last injection in the morning. Trunk blood was collected for measuring serum hormone levels and anterior pituitaries were rapidly removed and frozen on dry ice for mRNA studies.

Serum levels of LH, FSH, and estradiol levels were determined using established RIA methods. The antibodies were NIADDK rat-S7 (LH) and NIADDK rat-S11 (FSH); estradiol was measured by using a sensitive RIA (Diagnostic Systems
Laboratories) with a lower detection limit of $6 \mathrm{pg} / \mathrm{mL}$. Reference preparations were RP2 for both LH and FSH. For iodination, LH I-6 and FSH I-7 were used. To achieve maximum sensitivity $100 \mu \mathrm{L}$ serum was used for LH and FSH measurements. Each assay was performed with freshly prepared tracer that had been purified by fast protein liquid chromatographycolumn chromatography on Superdex 75 column (Amersham Pharmacia Biotech, Freiburg, Germany). In pilot experiments, fractions were tested for maximum sensitivity. Based on these data, an elution pattern of the chromatography with regard to the fraction containing the optimal tracer was established. Under these conditions sensitivity limits of $0.1 \mathrm{ng} / \mathrm{mL}(\mathrm{LH})$ and $0.4 \mathrm{ng} / \mathrm{mL}(\mathrm{FSH})$ were achieved. The intra-and interassay coefficients of variation from replicates of pooled samples from ovariectomized rats were $7.5 \%$ and $11.5 \%(\mathrm{LH})$ and $8.5 \%$ and $13.5 \%(\mathrm{FSH})$.

RNA-preparation and competitive RT-PCR. For generation of mutant RNA templates, composite primers were designed for each probe according to the method of Kephart (Promega Notes 68). These composite primers consist of the normal upstream or downstream primer sequence and a 15 -bp sequence region located up to 100 nucleotides downstream in the RNA. An RT-PCR reaction was carried out with composite primer plus the respective sense or antisense primer and the resulting PCR products were cloned using the TOPO cloning kit ${ }^{\circledR}$ (Invitrogen, Groningen, The Netherlands). After sequencing, the RNA was reverse transcribed with the Reverse Transcription System ${ }^{\circledR}$ purchased from Promega. The isolation of total RNA from individual anterior pituitaries from animals in the second experiment was carried out with the RNeasy Total RNA Kit (Qiagen, Hilden, Germany) according to the manufacturer's protocol. RNA concentrations were measured using the RiboGreen ${ }^{(i x)}$ RNA quantitation reagent (Molecular Probes, Eugene, Oregon, U.S.A.). RT-PCR was conducted using SUPERSCRIPT ${ }^{\circledR \times}$ for RT and SUPERMIX ${ }^{\circledR}$ for PCR (both purchased from GIBCO-BRL, Eggenstein, Germany). The RT reaction was carried out with $150 \mathrm{ng}$ total RNA. Before RT-PCR reaction, various amounts of mutant RNA were added to all reaction vials. The concentration of this cRNA was evaluated for each investigated gene by pilot titration experiments using $150 \mathrm{ng}$ native RNA co-reverse transcribed and subsequently co-amplified with a serial dilution of the corresponding mutant cRNA as previously described (19). For PCR reaction, $1-3 \mu \mathrm{L}$ cDNA and $25 \mathrm{pM}$ primer were

Table 1. Primer pairs for competitive PCR for encoding $m R N A$ sequences according to Kaiser et al. (GnRH-R), Chin et al. (LH- $\beta$ ), Kato et al. (FSH- $\beta)$, and Godine et al. (alpha subunit)

\begin{tabular}{|c|c|c|c|}
\hline Probe & & Primer sequence & $\begin{array}{l}\text { No. of } \\
\text { cycles }\end{array}$ \\
\hline \multirow[t]{2}{*}{ GnRH-R } & $5^{\prime}$ & TCAGTGGTATGCTGGAGAGT & 30 \\
\hline & $3^{\prime}$ & ATATAAGTGGGTCGAAGCAC & \\
\hline \multirow[t]{2}{*}{ LH- $\beta$} & $5^{\prime}$ & TGCAGAGAAGAATGAGTTCTGCC & 24 \\
\hline & & CTCAACCAATGACCTGTGAC & \\
\hline \multirow[t]{2}{*}{ FSH- $\beta$} & & CTCCTCAGGATCTGGTGTAT & 27 \\
\hline & & ACCATCGGCTCCTCTATTGT & \\
\hline \multirow[t]{2}{*}{ alpha subunit } & & TATGCGGCTGTCATTCTGGT & 22 \\
\hline & & TCCACAAGTCGTAGCTTCCA & \\
\hline
\end{tabular}


added to the SUPERMIX solution. Table 1 shows primer pairs and numbers of cycles used for RT-PCR of native mRNA $(20-23)$. The amplified PCR products were size-fractionated by electrophoresis in a $1.5 \%$ agarose gel in tris borate ethylene diamine tetracetic acid buffer and photographed after staining with ethidium bromide. Intensities of bands were evaluated with the Kodak DC 1D program.

Statistical evaluation and mathematical calculations. Unless otherwise stated, results are presented as mean \pm SEM. All data from the RIA and PCR analysis were statistically evaluated with one-way ANOVA followed by Dunnet's multiple $t$ test using the Prism ${ }^{\circledR}$ program (GraphPad Software, Inc. San Diego, CA, U.S.A.). In case of nonparametric distribution (serum gonadotropins), the statistical analysis was performed for each of the four time points separately on the significance level alpha $=0.05$ by using SAS 6.12 for Windows (SASInstitute, Cary, NC, U.S.A.). The exact Kruskal-Wallis test was used to compare multiple groups, whereas the exact MannWhitney test was used for comparisons in pairs. Differences were considered significant if $p<0.05$.

\section{RESULTS}

Pubertal development, weights and serum hormones. In both experiments all treated animals appeared to be healthy. The body weight gain and the weights at $\mathrm{d} 37$ were similar for all groups of both studies. Pubertal development was inhibited by all three GnRH analogues, as determined by lower percent-
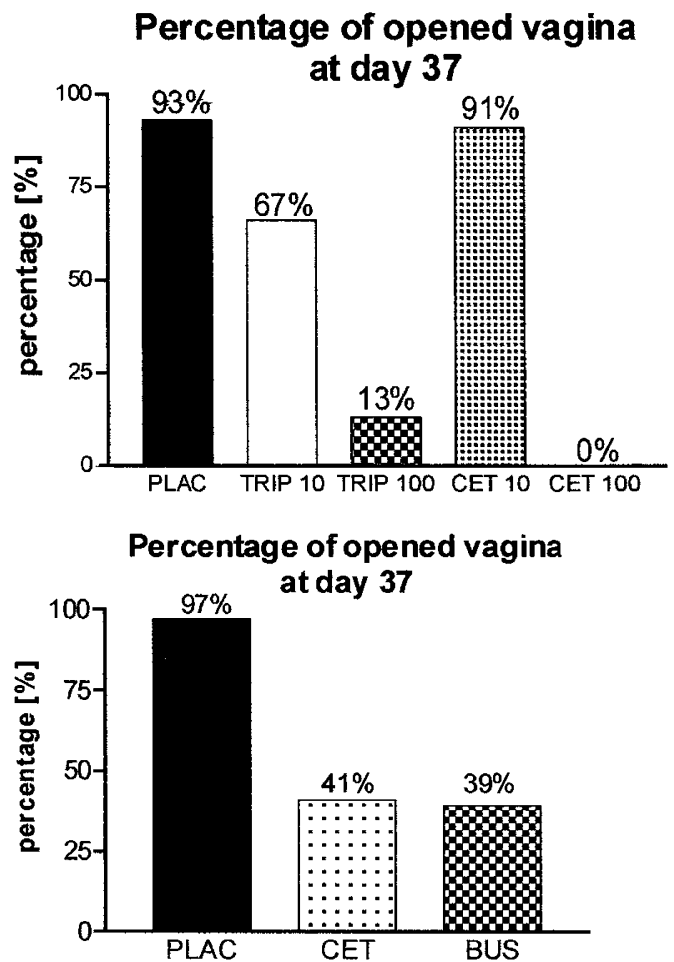

Figure 1. Percentage of opened vagina on postnatal d 37. At pubertal age there was a lower percentage of rats with opened vagina after treatment with TRIP or CET versus controls (PLAC) ( $a$, experiment 1 ) or after treatment with BUS or CET versus controls ( $b$, experiment 2 ). Delay of onset of puberty was dose dependent in $\mathrm{GnRH}$ analogue-treated rats. Vaginal opening was completely abolished in the CET $100 \mu \mathrm{g} / \mathrm{d}$ group of experiment 1 .
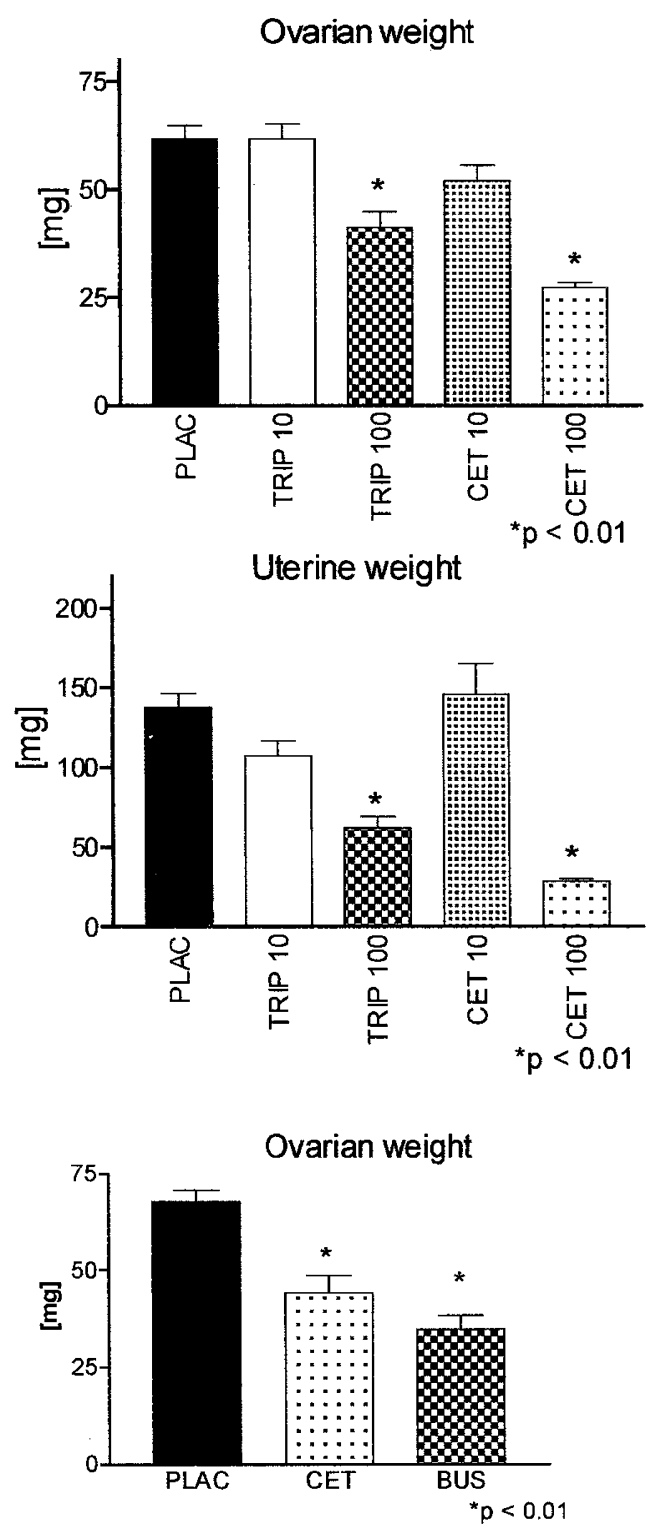

Figure 2. Ovarian and uterine development. $(a, b)$ Experiment 1: after $12 \mathrm{~d}$ treatment, ovarian weights and uterine weights were significantly lower in animals treated with TRIP $100 \mu \mathrm{g} / \mathrm{d}$ or CET $100 \mu \mathrm{g} / \mathrm{d}$ compared with controls, whereas TRIP $10 \mu \mathrm{g} / \mathrm{d}$ or CET $10 \mu \mathrm{g} / \mathrm{d}$ had little effect. (c) Experiment 2: after $10 \mathrm{~d}$ treatment with either BUS $2 \times 30 \mu \mathrm{g} / \mathrm{d}$ or CET $1 \times 100 \mu \mathrm{g} / \mathrm{d}$ the ovarian weights were significantly lower than in controls.

age of vaginal opening at pubertal age versus controls (Fig. 1, $a$ and $b$ ). Efficiency of treatment was confirmed by the significant reduction of ovarian and uterine weights (Fig. 2, $a-c$ ).

In the first experiment, after the first injection of CET 100 $\mu \mathrm{g}$, serum LH levels were significantly lower in CET-treated rats, whereas in TRIP-treated rats significantly higher LH levels were found. Suppression of LH by CET and stimulation of LH release by TRIP was observed during the entire treatment (Table 2a). FSH levels were significantly lower under CET treatment and significantly higher after TRIP treatment compared with controls. FSH was more stimulated by TRIP 10 $\mu \mathrm{g} / \mathrm{d}$ than by TRIP $100 \mu \mathrm{g} / \mathrm{d}$ (Table $2 b$ ). In the second experiment, estradiol levels were significantly lower in both CET 
Table 2A. Serum LH levels at four time points during $12 d$ treatment in experiment 1

\begin{tabular}{|c|c|c|c|c|c|c|c|c|c|}
\hline \multirow{3}{*}{ Groups } & \multirow[b]{3}{*}{$n$} & \multicolumn{8}{|c|}{ Time point } \\
\hline & & & $\begin{array}{l}\text { r 1st } \\
\text { LH } \\
\text { L) }\end{array}$ & \multirow{2}{*}{\multicolumn{2}{|c|}{$\begin{array}{c}24 \mathrm{~h} \text { after } 3 \mathrm{rd} \text { injection } \\
\mathrm{LH}(\mathrm{ng} / \mathrm{mL})\end{array}$}} & \multirow{2}{*}{\multicolumn{2}{|c|}{$\begin{array}{c}2 \mathrm{~h} \text { after } 9 \text { th injection } \\
\mathrm{LH}(\mathrm{ng} / \mathrm{mL})\end{array}$}} & \multirow{2}{*}{\multicolumn{2}{|c|}{$\begin{array}{c}14 \mathrm{~h} \text { after } 12 \mathrm{th} \\
\text { injection } \mathrm{LH}(\mathrm{ng} / \mathrm{mL}) \\
\text { Mean } \pm \mathrm{SEM}\end{array}$}} \\
\hline & & \multicolumn{2}{|c|}{ Mean $\pm \mathrm{SEM}$} & & & & & & \\
\hline Controls & 15 & 0.28 & 0.04 & 0.55 & \multirow[t]{2}{*}{0.05} & 0.43 & 0.06 & 0.20 & 0.03 \\
\hline CET 100 & 16 & 0.13 & $0.01 *$ & $<0.10^{*}$ & & $<0.1 *$ & & $<0.1 *$ & \\
\hline CET 10 & 12 & 0.28 & 0.06 & 0.30 & $0.07 \dagger$ & 0.24 & $0.03 \dagger$ & 0.19 & 0.04 \\
\hline TRIP 100 & 15 & 1.12 & $0.15 \dagger \div$ & 0.88 & $0.12 \dagger \dagger \S$ & 3.05 & $0.42 * \div \S$ & 0.50 & $0.07 * \div \S$ \\
\hline TRIP 10 & 12 & 0.47 & 0.07 & 0.79 & 0.14 & 6.89 & $0.95 * \div \S$ & 0.69 & $0.09 * \div \S$ \\
\hline
\end{tabular}

$* p<0.001$ vs controls (same time point).

$\dagger p<0.05 v$ s controls (same time point).

$\ddagger p<0.001$ vs CET 100 (same time point).

$\S p<0.05$ vs CET 10 (same time point).

Table 2B. Serum FSH levels at four time points during $12 d$ treatment in experiment 1

\begin{tabular}{|c|c|c|c|c|c|c|c|c|c|}
\hline \multirow[b]{3}{*}{ Groups } & \multirow[b]{3}{*}{$n$} & \multicolumn{8}{|c|}{ Time point } \\
\hline & & \multicolumn{2}{|c|}{$\begin{array}{l}14 \mathrm{~h} \text { after } 1 \mathrm{st} \\
\text { injection } \mathrm{FSH} \\
(\mathrm{ng} / \mathrm{mL})\end{array}$} & \multicolumn{2}{|c|}{$\begin{array}{l}24 \mathrm{~h} \text { after } 3 \mathrm{rd} \\
\text { injection } \mathrm{FSH} \\
(\mathrm{ng} / \mathrm{mL})\end{array}$} & \multicolumn{2}{|c|}{$\begin{array}{c}2 \mathrm{~h} \text { after } 9 \text { th injection } \\
\text { FSH }(\mathrm{ng} / \mathrm{mL})\end{array}$} & \multicolumn{2}{|c|}{$\begin{array}{c}14 \mathrm{~h} \text { after } 12 \text { th injection } \\
\text { FSH }(\mathrm{ng} / \mathrm{mL})\end{array}$} \\
\hline & & \multicolumn{2}{|c|}{ Mean \pm SEM } & \multicolumn{2}{|c|}{ Mean \pm SEM } & \multicolumn{2}{|c|}{ Mean $\pm \mathrm{SEM}$} & \multicolumn{2}{|c|}{ Mean \pm SEM } \\
\hline Controls & 15 & 2.13 & 0.5 & 1.03 & 0.4 & 2.31 & 0.9 & 1.39 & 0.5 \\
\hline CET 100 & 16 & $<0.4^{*}$ & & $<0.4 \dagger$ & & $<0.4 \dagger$ & & $<0.4^{*}$ & \\
\hline CET 10 & 12 & 1.68 & 0.7 & 0.49 & 0.1 & 0.63 & 0.2 & 1.88 & 0.6 \\
\hline TRIP 100 & 15 & 4.09 & $1.2 \div$ & 6.99 & $1.5 * \div \S$ & 12.10 & $1.9 *+\S$ & 3.82 & $1.1+t$ \\
\hline TRIP 10 & 12 & 4.80 & $0.8 \div$ & 13.08 & $1.9 * \div \S$ & 17.66 & $4.4^{*}+\S$ & 11.14 & $1.3 * \$ \S$ \\
\hline
\end{tabular}

$* p<0.001$ vs controls (same time point).

$\dagger p<0.05$ vs controls (same time point).

$\$ p<0.001$ vs CET 100 (same time point).

$\S p<0.05$ vs CET 10 (same time point).

and BUS treated rats (Fig. 3a). Two hours after the last injection, serum LH levels were again suppressed by CET and stimulated by the agonist BUS (Fig. $3 b$ ). FSH levels showed no significant change after CET treatment but were significantly higher after BUS treatment compared with controls (Fig. 3c).

Gene expression of pituitary GnRH receptor and gonadotropin subunits. In experiment 2 (CET versus BUS), treatment with $\mathrm{CET}$ caused a significant reduction of the gene expression of the GnRH receptor in the pituitary. In contrast, in BUStreated rats the amount of GnRH receptor mRNA was slightly though not significantly higher than in the control group (Fig. 4). Likewise, expression of gonadotropin subunit LH- $\beta$ was lowered by CET whereas there was no effect in BUS-treated rats. FSH- $\beta$ expression and alpha subunit expression were significantly stimulated by BUS, but CET treatment did not change the mRNA levels of either hormone subunits (Fig. 5).

\section{DISCUSSION}

To our knowledge this is the first study in which the inhibitory effect of the GnRH antagonist CET on sexual maturation and on pituitary gene expression has been compared with the effects of the GnRH agonists TRIP and BUS. Our results demonstrate that each of the three $\mathrm{GnRH}$ analogues retards pubertal and gonadal development as indicated by a lower percentage of vaginal opening at pubertal age and, in particular, by lower ovarian weights and reduced estradiol levels. Even after shortening the treatment period, as in experiment 2, a profound inhibition of pubertal development was observed.

In CET-treated rats the serum LH and FSH levels were reduced, whereas during and after treatment with BUS or TRIP the serum LH and FSH levels were elevated. Nevertheless, retarded onset of pubertal development, lower ovarian and uterine weights, and lower estradiol levels were observed in the present study, implying that each GnRH analogue in effect inhibits the release of bioactive gonadotropins. The most likely explanation for this observation is that CET directly inhibits pituitary gonadotropin secretion whereas BUS and TRIP may cause intrinsic release of bioinactive gonadotropins. Supporting this idea are reports that in humans BUS releases bioinactive LH molecules into the circulation that are detected by RIA using polyclonal antibodies but not by immunoassays based on monoclonal antibodies $(24,25)$. This hypothesis of bioinactive LH release caused by GnRH agonists is supported by the observation that sera from women under BUS treatment do not stimulate testosterone production in the mouse interstitial cell in vitro bioassay (26). An alternative explanation for the elevated GnRH agonist-caused gonadotropin levels is that TRIP and BUS may cause a transient flare-up. To assess this phenomenon we collected blood samples at different time intervals $(2 \mathrm{~h}, 14 \mathrm{~h}$, and $24 \mathrm{~h})$ after treatment. Our observations in this study contradicted the transient factor in the flare-up 


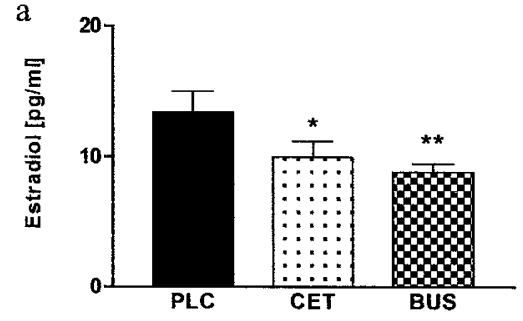

b

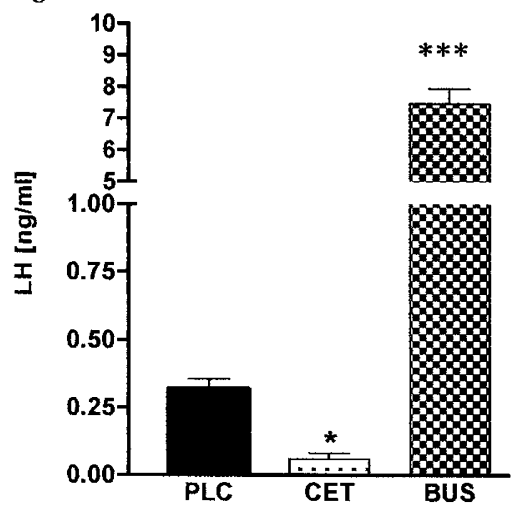

$\mathrm{c}$

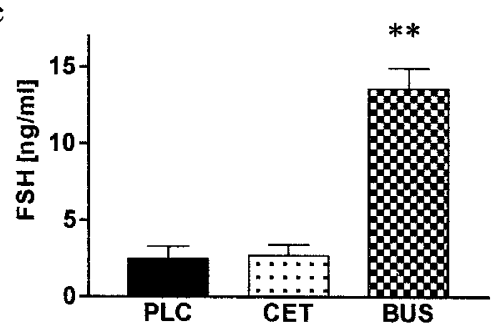

Figure 3. Serum hormones at end of 10-d treatment with CET, BUS, or placebo (PLAC) in experiment 2. (a) Estradiol levels were lower in CET and BUS treated rats compared with controls. (b) Two hours after last injection, serum LH levels were lower in CET-injected rats but higher in BUS-treated rats compared with controls. (c) Serum FSH levels showed no significant change after CET treatment but were significantly higher in BUS-injected animals compared with controls. ${ }^{*} p<0.05,{ }^{* *} p<0.01,{ }^{* * *} p<0.001$ compared with controls.

explanation. We consistently found significantly elevated $\mathrm{LH}$ and FSH concentrations in samplings up to $24 \mathrm{~h}$ after treatment. Similarly, in another study a 12-d treatment of male rats with BUS led to reduced testes size and lower serum testosterone but unchanged LH levels $24 \mathrm{~h}$ after the last injection (27). We postulate that after pretreatment with TRIP and BUS our RIA detected bioinactive rather than biologically active LH molecules, however further studies are needed to fully delineate the mechanisms of the GnRH analogues.

The low estradiol levels found in this study may be due to the lowered gonadotropin levels (in the case of CET) or, as discussed above, could also be the consequence of release of bioinactive LH (in the cases of TRIP and BUS) and/or a direct action of GnRH-analogues in the ovary. In fact, $\mathrm{GnRH}$ and its agonists are known to directly affect steroid production and proliferation of human and rat granulosa cells via specific GnRH receptors (28-30). Furthermore, the human and rat ovary have been found to express $\mathrm{GnRH}$, suggesting that the peptide may be involved in regulating the endocrine function of the ovary (31-33). Recent data also indicate that CET
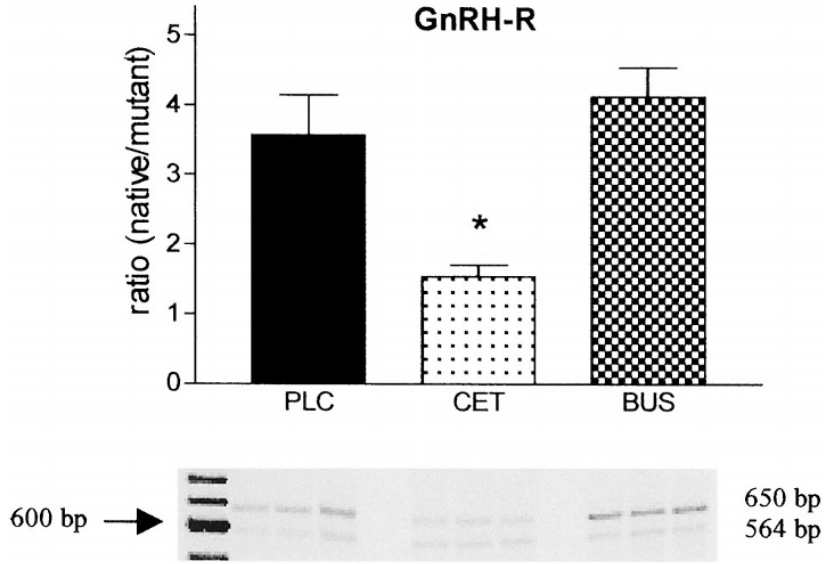

Figure 4. The pituitary gene expression of GnRH receptor in experiment 2. The ratio of native to mutant GnRH receptor DNA fragments was significantly lower in CET-treated rats compared with controls and BUS-injected animals. The gel shows triplicate values of different animals in the competitive PCR for GnRH receptor (650 bp) and mutant GnRH receptor (564 bp). Before PCR, the RT of each animal sample was carried out with same amount of mutant cRNA, ${ }^{*} p<0.01$ compared with controls.

reduces proliferation of granulosa cells more potently than BUS (34). Thus the possibility cannot be ruled out that CET reduces estradiol secretion not only by inhibiting LH release but also by directly reducing estradiol secretion via an ovarian mechanism. On the other hand, it may be possible that CET acts as an inhibitor of both the pituitary and ovary whereas agonists may not reduce gonadotropin release but directly act in the ovary.

To assess these putative divergent effects of CET versus BUS on the pituitary, we performed a second experiment with the focus on expression of relevant target genes in the pituitary. Only CET induced lower pituitary LH- $\beta$ gene expression that corresponded with lower LH serum levels. BUS stimulated LH and FSH levels along with elevated gene expression of the alpha-subunit and FSH- $\beta$ and slightly, but not significantly, increased amounts of LH- $\beta$-subunit mRNA. It should be emphasized that these observations were made $2 \mathrm{~h}$ after the last injection of the 10-d treatment.

Therapy of precocious puberty aims to prevent the action of untimely released endogenous GnRH by blocking the primary target, i.e. the pituitary, ideally causing a reduction of $\mathrm{GnRH}$ receptor gene expression and lower LH secretion because of "down-regulation" of the GnRH receptor. In our experiments with female peripubertal rats, only CET met both criteria, i.e. it inhibited GnRH receptor-mRNA levels in the pituitary and reduced gonadotropin levels in the serum. In a previous study with adult male rats it has been shown that CET decreased the number of GnRH receptor binding sites along with reduced GnRH receptor gene expression (35). It appears that CET prevents the binding of endogenous $\mathrm{GnRH}$ to its receptor without appreciable intrinsic effect on LH biosynthesis and release.

Further support for the lack of intrinsic effects of CET comes from a clinical study on normal men. In this study, after an initial high loading dose of CET, a lower daily maintenance dose was sufficient for suppression of LH, FSH, and testoster- 


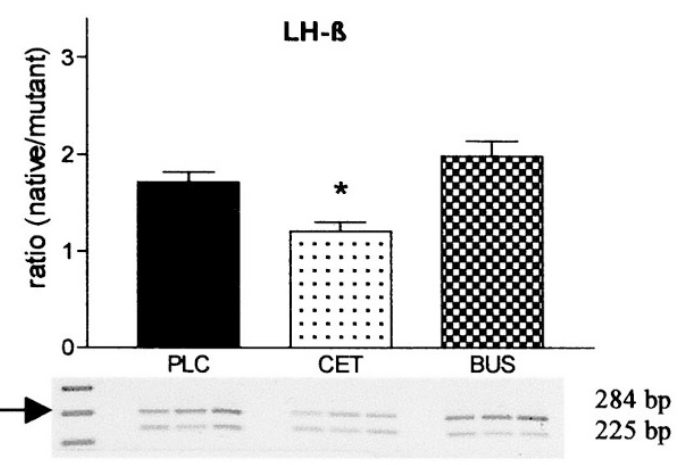

$300 \mathrm{bp}$

b

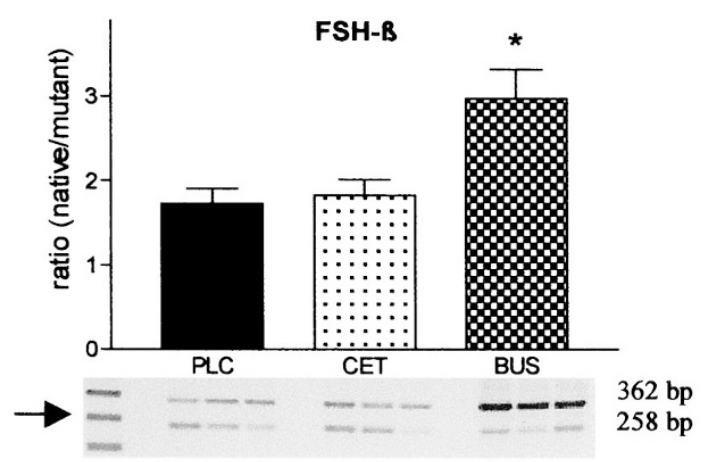

c

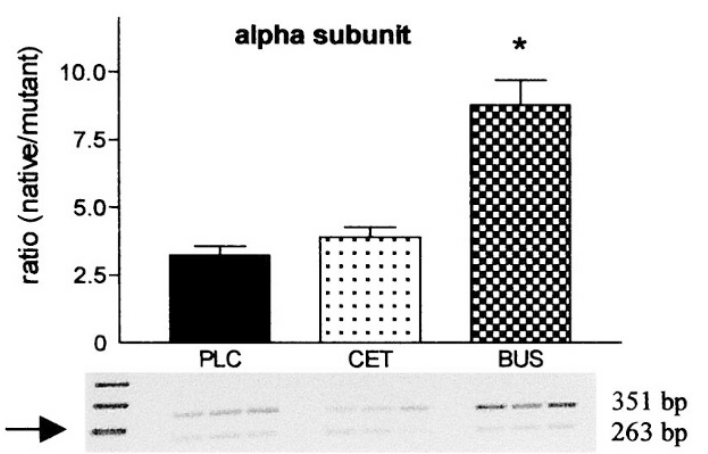

Figure 5. The pituitary expression of gonadotropin subunits in experiment 2 shown by ratio of native to mutant DNA fragments. Gels show representative triplicate values of different animals in competitive PCR for LH- $\beta$ (284 bp, mutant 225 bp), FSH- $\beta$ (362 bp, mutant 258 bp), and alpha subunit (351 bp, mutant $263 \mathrm{bp}$ ). RT of each animal sample was carried out with same amount of mutant cRNA. In CET-treated rats, LH- $\beta$ was lower than in BUS or placebo group, whereas BUS-treated animals had a significantly higher FSH- $\beta$ and alpha subunit expression, ${ }^{*} p<0.01$ compared with controls.

one (9). This reduction of the therapeutically efficient drug doses compared with the required continuation of regular injections of GnRH agonists to avoid reactivation of the gonadotropin and gonadal steroid hormone secretion may be advantageous in the use of CET versus agonists. It thus appears that GnRH antagonists may have two actions on the GnRH receptor: initially, and possibly most importantly, a competitive mechanism that prevents binding of endogenously released $\mathrm{GnRH}$ that is then followed by a down-regulation of pituitary GnRH receptors. This would explain the lower maintenance dose of the antagonists required for effective gonadotropin suppression.
This study shows that CET has only inhibiting effects on pituitary hormone secretion and gonadotropin subunit expression in peripubertal rats versus the stimulating as well as inhibiting effects observed for the GnRH agonists BUS and TRIP. Our data also suggest that CET affects pituitary LH release more specifically than BUS because of its parallel inhibition of transcription and secretion of LH. These more targeted effects coupled with CET's minimal side effects and lower maintenance dosage requirement would suggest that treatment of central precocious puberty is a potential clinical application for CET.

Acknowledgments. The authors thank Dr. Reissmann, ASTA Medica, Frankfurt, Germany, who kindly provided the drug cetrorelix acetate to us as a gift. We also thank M. Neff-Heinrich in editing this article, M. Metten for her kind support in the laboratory, and U. Munzel, Department of Medical Statistics, University of Göttingen, for statistical analysis of the data.

\section{REFERENCES}

1. Wildt L, Marshall G, Knobil E 1980 Experimental induction of puberty in the infantile female rhesus monkey. Science 207:1373-1375

2. Oostdijk W, Partsch CJ, Drop SLS, Sippell WG 1991 Long-term results with a slow-release gonadotropin-releasing hormone agonist in central precocious puberty. Dutch-German Precocious Puberty Study Group. Acta Paediatr Scand Suppl $372: 39-45$

3. Pescovitz OH, Barnes KM, Cutler Jr GB 1991 Effect of deslorelin dose in the treatment of central precocious puberty. J Clin Endocrinol Metab 72:60-64

4. Sippell WG, Partsch CJ, Hümmelink R, Lorenzen F 1991 Long-term therapy with delayed-action LHRH-agonist decapeptyl depot in girls with precocious puberty. Results of an international multicenter study. Gynäkologe 24:108-113

5. Plosker GL, Brogden RN 1994 Leuprorelin - a review of its pharmacology and therapeutic use in prostatic cancer, endometriosis and other sex hormone-related disorders. Drugs 48: 930-967

6. Haviv F, Bush EN, Knittle J, Greer J 1998 LHRH antagonists. Pharm Biotechnol 11:131-149

7. Felberbaum R, Diedrich K 1996 Klinischer Einsatz der GnRH-Analoga im Rahmen der Sterilitätstherapie: Agonisten und Antagonisten. Gynäkologe 29:420-432

8. Albano C, Felberbaum RE, Smitz J, Riethmuller-Winzen H, Engel J, Diedrich K, Devroey P 2000 Ovarian stimulation with HMG: results of a prospective randomized phase III European study comparing the LH-releasing hormone (LHRH)-antagonist cetrorelix and the LHRH-agonist buserelin. Hum Reprod 15:526-531

9. Behre HM, Kliesch S, Pühse G, Reissmann T, Nieschlag E 1997 High loading and low maintenance doses of a gonadotropin-releasing hormone antagonist effectively suppress serum LH, FSH, and testosterone in normal men. J Clin Endocrinol Metab 82: $1403-1408$

10. Oliviennes F, Alvarez S, Bouchard P, Fanchin R, Salat-Baroux J, Frydman R 1998 The use of GnRH antagonist (cetrorelix ${ }^{\circledR}$ ) in a single dose protocol in IVF-embryo transfer: a dose finding study of 3 versus 2 mg. Hum Reprod 13:2411-2414

11. Eckardstein A, Kliesch S, Nieschlag E, Chirazi A, Assmann G, Behre HM 1997 Suppression of endogenous testosterone in young men increases serum levels of HDL subclass lipoprotein A-I and lipoprotein (a). J Clin Endocrinol Metab 82:3367-3372

12. Lamharzi N, Schally AV, Koppan M 1998 LH-releasing hormone (LH-RH) antagonist cetrorelix inhibits growth of DU-145 human androgen-independent prostate carcinoma in nude mice and suppresses the levels and mRNA expression of IGF-II in tumors. Regul Pept 77:185-192

13. Comaru-Schally AM, Brannan W, Schally AV, Colcolough M, Monga M 1998 Efficacy and safety of LH-releasing hormone antagonist cetrorelix in the treatment of symptomatic benign prostatic hyperplasia. J Clin Endocrinol Metab 83:3826-3831

14. Bokser L, Srkalovic G, Szepeshazi K, Schally AV 1991 Recovery of pituitarygonadal function in male and female rats after prolonged administration of a potent antagonist of LH-releasing hormone (SB 75). Neuroendocrinology 54:136-145

15. Morale MC, Batticane N, Bartoloni G, Guarcello V, Farinella Z, Galasso MG, Marchetti B 1991 Blockade of central and peripheral LH-releasing hormone (LHRH) receptors in neonatal rats with a potent LHRH-antagonist inhibits the morphofunctional development of the thymus and maturation of the cell-mediated and humeral immune responses. Endocrinology 128:1073-1985

16. Phillips A, Hahn DW, Mc Guire JL, Ritchie D, Capetola RJ, Bowers C, Folkers K 1988 Evaluation of the anaphylactoid activity of a new LHRH antagonist. Life Sci 43:883-888. 
17. Feleder C, Jarry H, Leonhardt S, Moguilevsky JA, Wuttke W 1996 Evidence to suggest that gonadotropin-releasing hormone inhibits its own secretion by affecting hypothalamic amino acid neurotransmitter release. Neuroendocrinology 64:298-304

18. Halmos G, Schally AV, Pinski J, Vadillo-Buenfil M. Groot K 1996 Down-regulation of pituitary receptors for LH-releasing hormone (LH-RH) in rats by LH-RH antagonist cetrorelix. Proc Natl Acad Sci U S A 93:2398-2402

19. Seong JY, Jarry H, Kuhnemuth S, Leonhardt S, Wuttke W, Kim K 1995 Effect of GABAergic compounds on gonadotropin-releasing hormone receptor gene expression in the rat. Endocrinology 136:2587-2593

20. Kaiser UB, Zhao D, Cardona GR, Chin WW 1992 Isolation and characterization of cDNAs encoding the rat pituitary gonadotropin-releasing hormone receptor. Biochem Biophys Res Commun 189:1645-1652

21. Chin WW, Godine JE, Klein DR, Chang AS, Tan LK, Habener JF 1983 Nucleotide sequence of the cDNA encoding the precursor of the beta subunit of rat lutropin. Proc Natl Acad Sci U S A 80:4649-4653

22. Kato Y, Ezashi T, Hirai T, Kato T 1990 Strain difference in nucleotide sequences of rat glycoprotein hormone subunit cDNAs and gene fragment. Zool Sci 7:879-887

23. Godine JE, Chin WW, Habener JF 1982 Alpha subunit of rat pituitary glycoprotein hormones. Primary structure of the precursor determined from the nucleotide sequence of cloned cDNAs. J Biol Chem 257:8368-8371

24. Kwekkeboom DJ, Lamberts SW, Blom JH, Schroeder FH, De Jong FH 1990 Prolonged treatment with the GnRH analogue buserelin does not affect alpha-subunit production by the pituitary gonadotroph. Clin Endocrinol (Oxf) 32:443-451

25. Uemura T, Yanagisawa T, Shirasu K, Matsuyama A, Minaguchi H 1992 Mechanisms involved in the pituitary desensitization induced by gonadotropin-releasing hormone agonists. Am J Obstet Gynecol 167:283-291

26. Jaakkola T, Ding YQ, Kellokumpu-Lehtinen P, Valavaara R, Martikainen H, Tapanainen J 1990 The ratios of serum bioactive/immunoreactive LH and FSH in various clinical conditions with increased and decreased gonadotropin secretion: reevaluation by a highly sensitive immunometric assay. J Clin Endocrinol Metab $70: 1496-1505$
27. Huhtaniemi IT, Warren DD, Catt KJ 1983 Comparison of oestrogen and GnRH agonist analogue-induced inhibition of the pituitary-testicular function in rat. Acta Endocrinol (Copenh) 103:163-171

28. Hori H, Uemura T, Minaguchi H 1998 Effects of GnRH on protein kinase C activity, $\mathrm{Ca} 2+$ mobilization and steroidogenesis of human granulosa cells. Endocr J 45:175-182

29. Lin Y, Kahn JA, Hillensjo T 1999 Is there a difference in the function of granulosaluteal cells in patients undergoing in-vitro fertilization either with gonadotrophinreleasing hormone agonist or gonadotrophin-releasing hormone antagonist? Hum Reprod 14:885-888

30. Mori H, Ohkawa T, Takada S, Morita T, Yago N, Arakawa S, Okinaga S 1994 Effects of gonadotropin-releasing hormone agonist on steroidogenesis in the rat ovary. Horm Res 41(suppl 1):14-21

31. Saragueta PE, Lanuza GM, Baranao JL 1997 Inhibitory effect of gonadotrophinreleasing hormone $(\mathrm{GnRH})$ on rat granulosa cell DNA synthesis. Mol Reprod Dev 47:170-174

32. Uemura T, Namiki T, Kimura A, Yanagisawa T, Minaguchi H 1994 Direct effects of gonadotropin-releasing hormone on the ovary in rats and humans. Horm Res 41(suppl 1):7-13

33. Kang SK, Choi KC, Cheng KW, Nathwani PS, Auersperg N, Leung PC 2000 Role of gonadotropin-releasing hormone as an autocrine growth factor in human ovarian surface epithelium. Endocrinology 141:72-80

34. Yano T, Yano N, Matsumi H, Morita Y, Tsutsumi O, Schally AV, Taketani Y 1997 Effect of LH-releasing hormone analogs on the rat ovarian follicle development Horm Res 48(suppl 3):35-41

35. Pinski J, Lamharzi N, Halmos G, Groot K, Jungwirth A, Vadillo-Buenfil M, Kakar SS, Schally AV 1996 Chronic administration of the LH-releasing hormone (LHRH) antagonist cetrorelix decreases gonadotrope responsiveness and pituitary LHRH receptor mRNA levels in rats. Endocrinology 137:3430-3436 